\section{Interaction of Huanglongbing and Foliar Applications of Copper on Growth and Nutrient Acquisition of Citrus sinensis cv. Valencia}

\author{
Robert C. Ebel ${ }^{1}$, Said Hamido, and Kelly T. Morgan \\ Southwest Florida Research and Education Center, University of Florida, \\ 2685 State Road 29 North, Immokalee, FL 34142
}

Additional index words. greening, Candidatus Liberibacter asiaticus, Xanthomonas citri ssp. citri, citrus canker, essential nutrients

\begin{abstract}
The following study was conducted in 2016 and 2017 to determine the impact of frequent foliar copper (Cu) applications on Huanglongbing (HLB)-affected Citrus sinensis cv. Valencia orange. The experiment was conducted in a psyllid-free greenhouse with HLB-positive and non-HLB control trees grown in an Immokalee fine sand soil. The trees were well-maintained to promote health. $\mathrm{Cu}$ was applied to the foliage at $0 \mathrm{x}, 0.5 \mathrm{x}$, $1 x$, and $2 x$ the commercially recommended rates, which were $0,46,92$, and $184 \mathrm{~mm}$, respectively, with applications made $3 x$ in both 2016 and 2017. The impact of HLB and $\mathrm{Cu}$ treatments on leaf and root $\mathrm{Cu}$ concentrations, vegetative growth, Candidatus Liberibacter asiaticus ( $C$ Lasiaticus) genome copy number, and acquisition of other essential nutrients were determined. HLB caused the roots to acidify the soil more than non-HLB controls, which promoted $\mathrm{Cu}$ availability and promoted greater $\mathrm{Cu}$ concentrations in leaves and roots. $\mathrm{HLB}$ and $\mathrm{Cu}$ application treatments suppressed leaf area and total root length observable in rhizotron tubes such that, by the end of the experiment, leaf, stem, root, and whole-plant dry weights were reduced. HLB reduced foliar concentrations of calcium (Ca), magnesium (Mg), manganese (Mn), zinc ( $\mathrm{Zn})$ and possibly iron (Fe), but HLB did not affect root concentrations of these same essential nutrients. $\mathrm{Cu}$ application treatments did not affect leaf or root concentrations of other essential nutrients except foliar concentration of $\mathrm{Fe}$, which may have been suppressed. Foliar applications of $\mathrm{Cu}$ are used to suppress Xanthomonas citri ssp. citri $(\mathrm{Xcc})$ the causal agent of citrus canker, and the frequency of its use may need to be reconsidered in commercial groves.
\end{abstract}

HLB is the most serious disease of citrus where it has become endemic, including Florida (Bové, 2006; da Graça et al., 2016; Gottwald, 2010). HLB in Florida is associated with the phloem-limited bacteria $C \mathrm{La}-$ siaticus, which has a massive impact on the plant's physiology, growth, development, and productivity, causing whole-plant decline (Ebel, 2017). There is currently no technology that can suppress significantly and economically the bacteria in commercial citrus groves. The bacteria are vectored by the Asian citrus psyllid (Diaphorina citri Kuwayama), and the inability to suppress the vector's population adequately, coupled with its ability to increase exponentially, has led to infection of more than $80 \%$ of trees across the state (Gottwald, 2010). Once inoculated, the causal agent is apparently capable of reproducing and circulating throughout the tree such that it is permanently affected by HLB (Ebel, 2017). The severe decline observed in commercial groves is a function of repeated inoculation of the bac-

Received for publication 30 Oct. 2018. Accepted for publication 6 Dec. 2018.

${ }^{1}$ Corresponding author. E-mail: rcebel@ufl.edu or IPHS_Ebel@yahoo.com. teria by the psyllid vector and secondary stressors. The impact of HLB on tree growth and development as well as the tree's increased sensitivity to secondary stressors is forcing commercial grove managers in Florida to reevaluate the entire spectrum of horticultural management practices with the twin goals of suppressing the psyllid vector stressors.

One potential secondary stressor of HLBaffected citrus trees may arise from the frequent applications of $\mathrm{Cu}$ to suppress citrus canker caused by Xcc. Citrus canker was found in Florida in 1996 and has since become endemic throughout the state (Bouffard, 2006). Canker is another very serious disease of citrus that can cause defoliation, stem dieback, and fruit abscission (Gottwald and Graham, 2000). Foliar applications of $\mathrm{Cu}$ are a popular method for suppressing $X c c$ as a result of their low cost. Because the life cycle of $X c c$ is 7 to $21 \mathrm{~d}$ (Brunings and Gabriel, 2003; Ebel and Kumar, 2012), $\mathrm{Cu}$ applications as frequent as every 3 weeks have been used to suppress canker in severely affected groves. The overuse of $\mathrm{Cu}$ promotes high concentrations of $\mathrm{Cu}$ in soil that can reduce yields (Bakshi et al., 2013; Behlau et al., 2010; Fan et al., 2011). It population and minimizing all secondary is not known how high-frequency $\mathrm{Cu}$ applications on HLB-affected trees will impact tree growth, development, and productivity.

The following study was conducted to determine how frequent $\mathrm{Cu}$ applications may impact Citrus sinensis cv. Valencia affected by HLB. Because it is impossible to conduct studies with trees not infected with CLasiaticus under commercial conditions, this study was conducted under greenhouse conditions where psyllid vectors could be excluded so that non-HLB control trees would remain uninfected. Foliar applications of $\mathrm{Cu}$ were conducted in a manner that somewhat simulated commercial grove conditions, although the trees used here were not infected with $X c c$. The interaction of HLB and $\mathrm{Cu}$ treatments on $\mathrm{Cu}$ concentrations, vegetative growth, CLasiaticus genome copy number, and nutrient acquisition were evaluated.

\section{Materials and Methods}

Plant culture and HLB treatments. The experiment was conducted in a psyllid-free greenhouse at the University of Florida, Southwest Florida Research and Education Center near Immokalee, FL (lat. $26.42^{\circ} \mathrm{N}$, long. $\left.81.42^{\circ} \mathrm{W}\right)$ from 2016 to 2017 . The plants used were 7-year old Citrus sinensis (L.) Osbeck cv. Valencia on Swingle citrumelo (Citrus paradisi $\times$ Poncirus trifoliata) rootstock. One-year-old trees about $1 \mathrm{~m}$ high were obtained from a commercial nursery in 2009, planted in 10-L pots, and double budded with buds highly infected with $C \mathrm{La}$ siaticus, as reported previously (Handique et al., 2012). Before the experiment was initiated, the trees were well maintained in a psyllid-free greenhouse with daily irrigation, fertilization applications according to commercial recommendations, and suppression of insect pests as needed. In April 2016, 24 trees affected by HLB and 24 trees unaffected by HLB (control trees) were transplanted into 110 -L pots using Immokalee fine sand soil (sandy, siliceous, hyperthermic Arenic Alaquods), with the roots separated to encourage their exploration into the new soil. The trees were allowed to become established for 3 months before $\mathrm{Cu}$ treatments were initiated. The trees were $\approx 1.5 \mathrm{~m}$ in height when the experiment was initiated. Fruit were removed at the start of the experiment and after fruit set in 2017.

The HLB-affected trees were tested on 15 Feb. 2016 using real time-polymerase chain reaction according to $\mathrm{Li}$ et al. (2006). The cycle time $(\mathrm{Ct})$ of HLB-affected trees averaged 24.9, which indicates presence of the bacterial genome because the values were less than the threshold of 32. The trees exhibited mild HLB symptoms, including earlier shoot growth and bloom, veinal chlorosis, interveinal chlorosis, whole-leaf chlorosis, retarded leaf and shoot growth, dull cuticle, and slightly reduced growth. Trees were segregated based on leaf area such that the average leaf area per tree was similar for HLB-affected and non-HLB control trees and across $\mathrm{Cu}$ treatments to remove bias in tree 
size across all treatments when the experiment was initiated. Total leaf area was determined by counting total leaves per plant, measuring leaf area of 10 randomly selected leaves per tree using a portable leaf area meter (LI-3000A; LI-COR, Lincoln, NE), and multiplying the two quantities.

The trees were irrigated daily (until water dripped from the bottom of the pots) using microjet sprinklers that wetted most of the soil surface. The trees were fertilized with 20-2-20 NPK with $35 \mathrm{~g} /$ pot of $0.74 \%$ sulfur, $1.1 \% \mathrm{Mg}, 0.1 \% \mathrm{Fe}, 0.05 \% \mathrm{Mn}, 0.05 \% \mathrm{Zn}$, $0.025 \% \mathrm{Cu}$, and $0.025 \%$ boron (B) (Peat-Lite Low Phos Special; Peters Professional, Allentown, PA) every 2 to 5 weeks from July 2016 through Aug. 2017. The trees were also given foliar applications of $0.3 \%$ phosphorus (P), $1.2 \% \mathrm{Ca}, 3.6 \% \mathrm{Mg}, \mathrm{Fe}, 5.0 \% \mathrm{Mn}, 1.1 \%$ $\mathrm{Zn}, 0.003 \% \mathrm{Cu}$, and $2.7 \% \mathrm{~B}$ micronutrients (special formulation, Peters Professional) at $0.8 \mathrm{~g} /$ tree on 19 Oct. 2016 and $2.1 \mathrm{~g} /$ tree on 1 Nov. 2016. Soil pH was measured in May 2016 and Jan. 2017 by collecting soil samples from 0 to $15 \mathrm{~cm}$ and 15 to $30 \mathrm{~cm}$ from the soil surface and then pooling the samples for each tree. A subsample of $20 \mathrm{~cm}^{3}$ soil was placed in a $90-\mathrm{mL}$ cup to which $40 \mathrm{~mL}$ water was added. The water-soil solution was stirred, allowed to equilibrate for $30 \mathrm{~min}$, and the $\mathrm{pH}$ was measured (model AR15; Fisher Scientific, Hampton, NH).

$\mathrm{Cu}$ treatments. $\mathrm{Cu}$ treatments were $0 \mathrm{x}$, $0.5 \mathrm{x}, 1.0 \mathrm{x}$, and $2.0 \mathrm{x}$ the commercially recommended rate applied to the foliage of trees on 19 July, 11 Aug., and 30 Aug. in 2016; and 2 May, 6 June, and 26 July in 2017 . The rates corresponded to $0,46,92$, and $184 \mathrm{~mm}$, respectively, using $\mathrm{Cu}(\mathrm{OH})_{2}$, with the recommended rates as given on the product label (Kocide 2000; I.E. DuPont Canada Co., Mississauga, Ontario) with $2.5 \mathrm{~L}$ solution applied per tree. Four days after every treatment date, the foliage of each tree was rinsed with $2 \mathrm{~L}$ water (to simulate rainfall) to remove residual $\mathrm{Cu}$ from the foliage and move it onto the soil surface. This procedure somewhat mimic commercial conditions that exist during the rainy season in Florida, although under natural conditions precipitation is usually more frequent and of longer duration than that used in this study.

Vegetative growth. Measurement of total leaf area as described earlier was determined every 2 to 4 months.
Total observable root length was determined using clear rhizotron access tubes that were $52 \mathrm{~cm}$ long with a $64-\mathrm{mm}$ inner tube diameter. The tube was plugged at the bottom. The tubes were inserted into a hole augured vertically $\left(90^{\circ}\right)$ into the soil and 15 $\mathrm{cm}$ from the trunk. The tube spanned the distance from the bottom of the pot to the soil surface. Images were taken using a digital camera (model CI-600 In-Situ Root Imager; CID-Bioscience, Camas, WA) that allowed collection of $360^{\circ}$ images with a dimension of $21.59 \mathrm{~cm} \times 19.56 \mathrm{~cm}$ at 600 DPI. Roots were identified and analyzed using digital imaging software (Root Snap CI-690, version 1.3.2.25; CID-Bioscience). Before sampling on each sampling date, the scanner was calibrated according to the manufacturer's instructions.

In Dec. 2017, the trees were sampled destructively with leaves, stems, and roots separated; dried at $60^{\circ} \mathrm{C}$ to a constant weight; and dry weights were determined.

Foliar, root, and soil nutrient analysis. Leaf and root samples were collected using the procedures of Obreza and Morgan (2008); nutrient concentration was determined using standard analytical methods (Hanlon et al., 1997; Jones and Case, 1990; Plank, 1992). Leaf samples of 10 recently mature, fully expanded leaves were collected randomly from each tree and washed with laboratory detergent and $0.2 \mathrm{M} \mathrm{HCl}$ to remove residues. Root samples were collected by removing three $15-\mathrm{cm}$ deep-soil cores using a $1.3-\mathrm{cm}$ auger and rinsing the roots with tap and then distilled water. The process produced about $0.5 \mathrm{~g}$ roots after drying. Leaf and root samples were dried for $72 \mathrm{~h}$ at $60{ }^{\circ} \mathrm{C}$. When the tissues reached a constant weight, they were ground in a mill (model 5K907K; Dayton Electric Mfg., Co., Niles, IL) until all tissue passed through a 60-mesh sieve and was mixed thoroughly. Tissue nitrogen $(\mathrm{N})$ concentration (measured as a percentage) was determined using an NA2500 C/N Analyzer (Thermoquest CE Instruments LTD, Wigan, UK). Other essential nutrient concentrations were determined using a dry ash combustion digestion method (Anderson and Henderson, 1988). A 1.5-g sample of dried ground leaf material was weighed and dry-ashed at $500{ }^{\circ} \mathrm{C}$ for $16 \mathrm{~h}$ (Hanlon et al., 1997). The ash was equilibrated with $15 \mathrm{~mL}$ $0.5 \mathrm{M} \mathrm{HCl}$ at room temperature for $0.5 \mathrm{~h}$. The solution was decanted into $15-\mathrm{mL}$ plastic disposable tubes and placed in a refrigerator at $\leq 4{ }^{\circ} \mathrm{C}$ (Plank, 1992) until analyses by inductively coupled plasma atomic emission spectrometry (ICP-AES) (OPTIMA 7000DV; Perkin-Elmer, Billerica, MA) according to Munter et al. (1984). Tissue nutrient concentrations were compared with recommended levels for Florida citrus (Obreza and Morgan, 2008; Obreza et al., 1999).

Soil nutrient analysis was conducted by removing $2.5 \mathrm{~g}$ of dry soil and placing it into $50-\mathrm{mL}$ centrifuge tubes with $25 \mathrm{~mL}$ of Mehlich-3 extracting solution (Mehlich, 1984). Tubes were covered and shaken for 5 min then filtered through Whatman no. 42 filter paper. Soil essential nutrient concentrations were determined by ICP-AES.

Experimental design and statistical analysis. This study was conducted as a two HLB treatment (HLB and control)-by-four $\mathrm{Cu}$ application treatment $(0 \mathrm{x}, 0.5 \mathrm{x}, 1.0 \mathrm{x}$, and $2.0 \mathrm{x}$, which correspond to $0,46,92$, and $184 \mathrm{~mm}$, respectively) factorial, completely randomized design. There were six replications per treatment, although some data were collected on only three reps per tree where noted. All data were analyzed using the Statistical Analysis System (SAS for Windows, ver. 9.4; SAS Institute Inc., Cary, NC). Data analyzed over time (months) were analyzed using Proc Mixed with time (month) included as a repeated measure. Proc GLM was used for analyses in which repeated measures were not a factor or when there were too many likelihood evaluations for the Proc Mixed model. Regression equations were determined using Proc REG.

\section{Results and Discussion}

$\mathrm{Cu}$ in leaves, soil, and roots. There was a significant $\mathrm{HLB} \times \mathrm{Cu}$ treatment $\times$ months after $\mathrm{Cu}$ treatment interaction $(\mathrm{P}>\mathrm{F}<0.01)$ for $\mathrm{Cu}$ concentration of leaves (Table 1). Increasing the concentration of $\mathrm{Cu}$ led to greater foliar $\mathrm{Cu}$ concentrations for both HLB and control trees (Fig. 1A). Foliar $\mathrm{Cu}$ declined when $\mathrm{Cu}$ applications were ended (e.g., from Oct. 2016 to Apr. 2017), most likely via extrusion that occurs when symplastic $\mathrm{Cu}$ concentrations reach excessive levels (Marschner, 1995). The HLB $\times \mathrm{Cu}$ treatment interaction was also significant

Table 1. Results $(P>\mathrm{F})$ of the Proc Mixed (with MAFT) and Proc GLM (without MAFT) models on in planta $\mathrm{Cu}$ concentrations, vegetative growth, and soil pH of Huanglongbing (HLB)-affected 'Valencia' trees treated with multiple foliar applications of $\mathrm{Cu}$ and with dependent variables measured over time.

\begin{tabular}{|c|c|c|c|c|c|c|c|c|c|c|}
\hline \multirow{2}{*}{$\begin{array}{l}\text { Model variables and } \\
\text { interactions }\end{array}$} & \multicolumn{3}{|c|}{$\mathrm{Cu}(\mathrm{mg} / \mathrm{kg}$ dry $\mathrm{wt})$} & \multirow{2}{*}{$\begin{array}{r}\text { Leaf area } \\
\left(\mathrm{m}^{2} / \text { plant }\right)\end{array}$} & \multirow{2}{*}{$\begin{array}{c}\text { Root } \\
\text { length }(\mathrm{cm})\end{array}$} & \multicolumn{4}{|c|}{ Dry wt at end of expt. (kg dry wt) } & \multirow[b]{2}{*}{ Soil pH } \\
\hline & Leaf & Soil & Root & & & Leaf & Stem & Root & Plant & \\
\hline HLB & 0.75 & 0.25 & 0.41 & 0.06 & $<0.01$ & $<0.01$ & $<0.01$ & $<0.01$ & $<0.01$ & 0.96 \\
\hline MAFT & $<0.01$ & $<0.01$ & $<0.01$ & $<0.01$ & 0.10 & - & - & - & - & $<0.01$ \\
\hline $\mathrm{HLB} \times \mathrm{MAFT}$ & 0.90 & - & 0.70 & $<0.01$ & 0.02 & - & - & - & - & $<0.01$ \\
\hline $\mathrm{Cu} \times \mathrm{MAFT}$ & $<0.01$ & - & $<0.01$ & $<0.01$ & 0.02 & - & - & - & - & 0.81 \\
\hline
\end{tabular}

Bold values are referenced in the text.

MAFT $=$ months after foliar treatment with $\mathrm{Cu}(\mathrm{n}=6)$. 

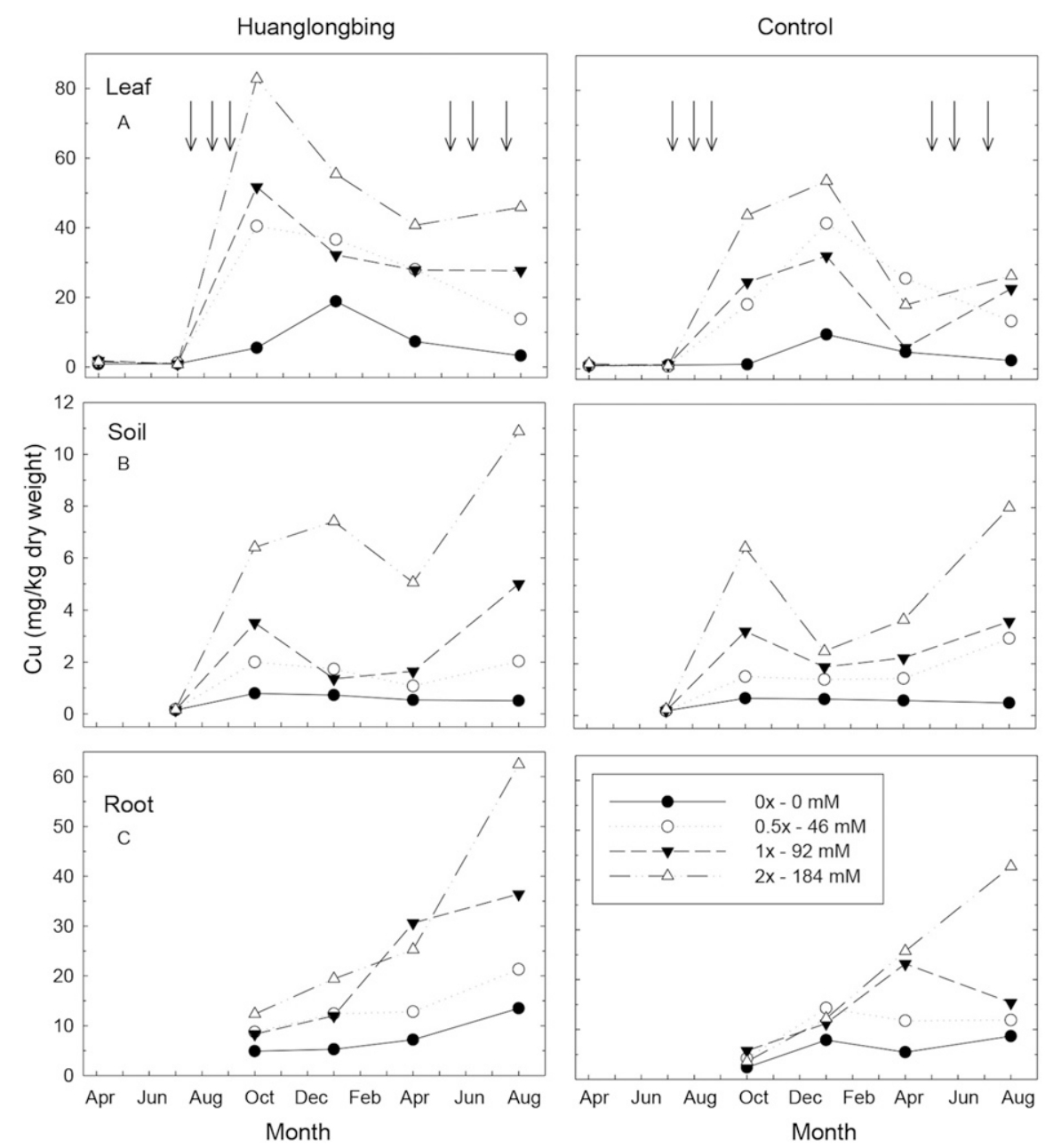

Fig. 1. Interaction of Huanglongbing and foliar applications of copper $(\mathrm{Cu})$ at $0 \mathrm{x}, 0.5 \mathrm{x}, 1 \mathrm{x}$, and $2 \mathrm{x}$ the recommended rates on $\mathrm{Cu}$ concentrations of mature leaves $(\mathbf{A})$, soil $(\mathbf{B})$, and roots $(\mathbf{C})$ of Citrus sinensis $\mathrm{cv}$. Valencia $(\mathrm{n}=6)$. Vertical arrows indicate dates of $\mathrm{Cu}$ foliar treatments. Symbols and line designations for $\mathrm{Cu}$ treatments are located in the legend in the lower right graph.

$(P>\mathrm{F}<0.01)$, with greater $\mathrm{Cu}$ rates allowing for greater accumulation of $\mathrm{Cu}$ in HLBaffected leaves than in control leaves, indicating a synergistic response (Fig. 2A). The foliar applications of $\mathrm{Cu}$ increased leaf $\mathrm{Cu}$ concentrations above the upper limit considered sufficient for citrus $(16 \mathrm{mg} / \mathrm{kg}$ dry weight) at lower rates of $\mathrm{Cu}$ applied for the HLB-affected trees than the non-HLB controls. The impact of HLB on Cu uptake has not been defined clearly in the literature, with some studies indicating suppression (Nwugo et al., 2013a, 2013b; Spann and Schumann, 2009), some indicating no effect (Handique et al., 2012; Masaoka et al., 2011; Tian et al., 2014), and, in a recent study, an increase (Hamido et al., 2017), although the $\mathrm{Cu}$ foliar analysis in that study was not published (Morgan, personal communication).

Rinsing leaves with water after $\mathrm{Cu}$ applications moved excess $\mathrm{Cu}$ to the soil, with soil concentrations as high as $11 \mathrm{mg} / \mathrm{kg}$ dry weight (Fig. 1B). Soil Cu concentration decreased between foliar applications from Oct. 2016 to April 2017 most likely through uptake by roots and leaching. There were too many likelihood evaluations for soil $\mathrm{Cu}$ concentrations to be analyzed using a Proc Mixed model analysis, so a Proc GLM analysis was conducted instead, with data blocked by months after foliar treatment with $\mathrm{Cu}$ (MAFT) (Table 1). There was no HLB effect on soil $\mathrm{Cu}$, but soil $\mathrm{Cu}$ increased with greater $\mathrm{Cu}$ application rates $(P>\mathrm{F}<0.01)$, as shown in Fig. 2B.

It would be expected that greater $\mathrm{Cu}$ in soil would promote uptake of $\mathrm{Cu}$ by roots, and this did occur, as indicated by the significant $\mathrm{Cu}$ treatment $\times$ MAFT interaction (Table 1: $P>\mathrm{F}<0.01$ ). Whether there was a preferential uptake of $\mathrm{Cu}$ by HLB-affected roots is less clear than it was for leaves (Fig. 1C). The $\mathrm{HLB} \times \mathrm{Cu}$ treatment $\times$ MAFT interaction in $\mathrm{Cu}$ concentration of roots was only significant at the $P>\mathrm{F}=0.20$ level, and the $\mathrm{HLB} \times \mathrm{Cu}$ treatment interaction was only significant at $P>\mathrm{F}=0.14$ (Table 1), both of which do not suggest an effect of HLB on root $\mathrm{Cu}$ concentration. However, when root $\mathrm{Cu}$ concentrations were regressed against foliar application concentrations, there was a trend for HLB-affected roots to have greater $\mathrm{Cu}$ concentrations, with $P>\mathrm{F}<0.01$ for both regressions (Fig. 2C). The greater acquisition

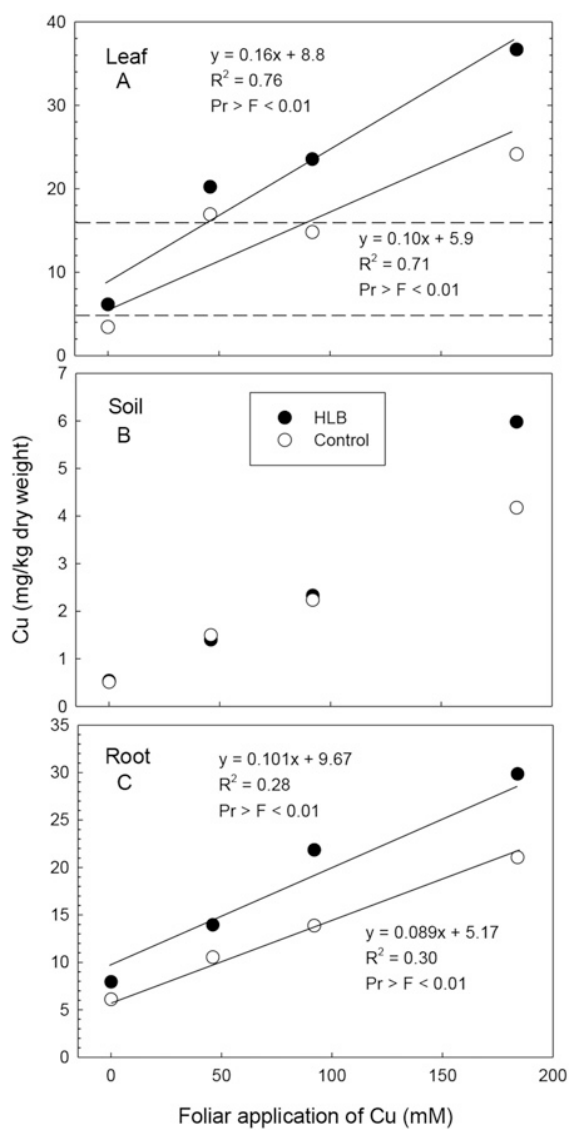

Fig. 2. Interaction of Huanglongbing (HLB) and foliar applications of copper $(\mathrm{Cu})$ on leaf $(\mathbf{A})$, soil (B), and root $(\mathbf{C}) \mathrm{Cu}$ concentrations of Citrus sinensis $\mathrm{cv}$. Valencia $(\mathrm{n}=6)$. The area within the horizontal dashed lines represents the range of foliar $\mathrm{Cu}$ concentration considered sufficient (5-16 mg/kg dry weight) (Obreza and Morgan, 2008). Symbols for HLB treatments are in the legend in the middle graph. Data used in the regression analyses were averaged across all sampling dates after the first $\mathrm{Cu}$ treatment was applied for each replication (tree); however, only overall means are shown in the graph.

and/or retention of root $\mathrm{Cu}$ with increasing $\mathrm{Cu}$ application rates indicate at least an additive and possibly a synergistic response for HLB-affected roots. The $\mathrm{Cu}$ concentration of roots at the $1 \mathrm{x}$ rate was 18.9 and $13.4 \mathrm{mg} \mathrm{Cu} / \mathrm{kg}$ dry weight for the HLBaffected and non-HLB roots, respectively, which represented a $42 \%$ increase caused by HLB. The low $R^{2}$ values for both regressions (0.28 and 0.30) indicate high plantto-plant variation. Unlike leaves, which excreted excess $\mathrm{Cu}$, roots accumulated $\mathrm{Cu}$ throughout the study, and an absolute limit-assuming one exists - was never reached, as indicated by no asymptote having occurred (Fig. 1C).

Impact of foliar $\mathrm{Cu}$ treatments on CLasiaticus genome copy number. To determine the impact of $\mathrm{Cu}$ treatments on the CLasiaticus genome copy number of HLBaffected plants, Ct values taken Oct. 2016, which was after the first three $\mathrm{Cu}$ treatments were applied, were compared with those 


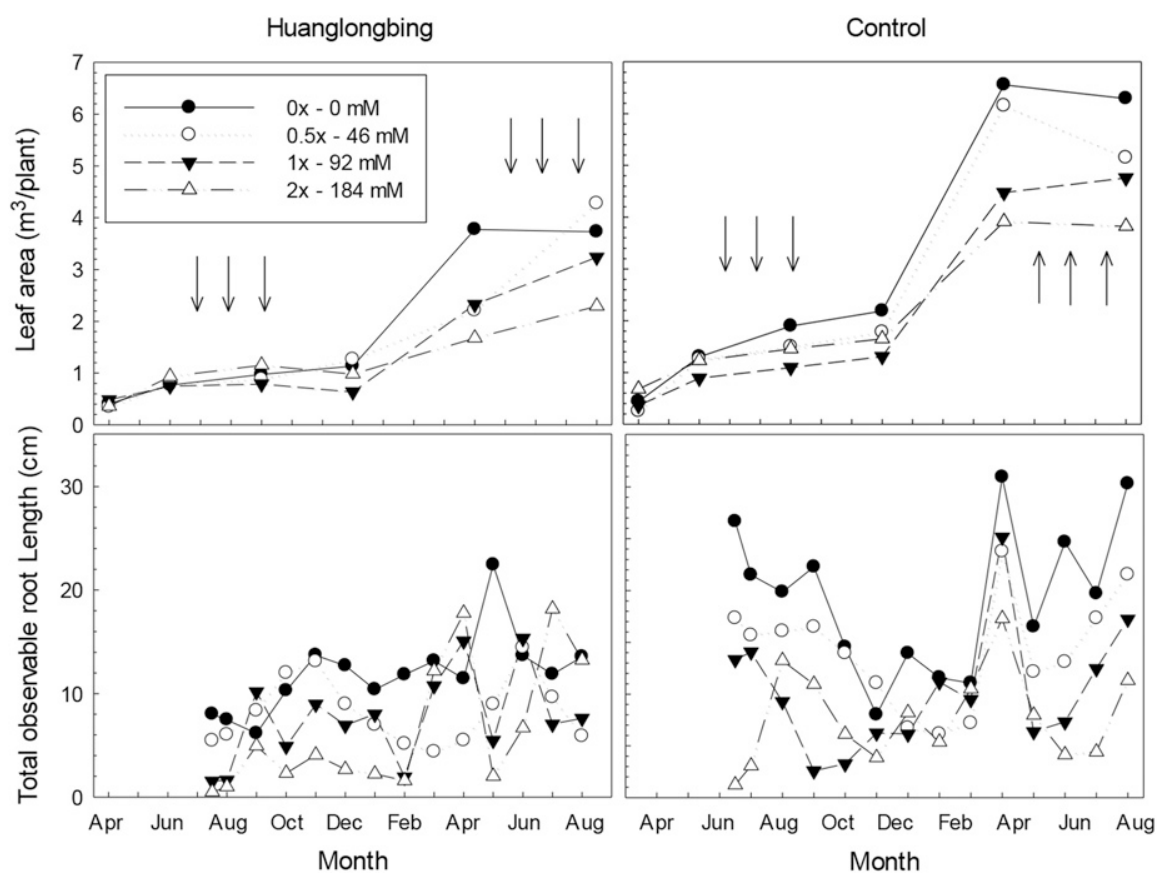

Fig. 3. Change in leaf area and total root length visible in the rhizotron tubes over time of Citrus sinensis cv. Valencia affected by Huanglongbing and foliar applications of copper $(\mathrm{Cu})$ at $0 \mathrm{x}, 0.5 \mathrm{x}, 1 \mathrm{x}$, and $2 \mathrm{x}$ the recommended rates $(n=3)$. Vertical arrows indicate dates of $\mathrm{Cu}$ foliar treatments. Symbols and lines for $\mathrm{Cu}$ treatments are in the legend in the upper left graph.

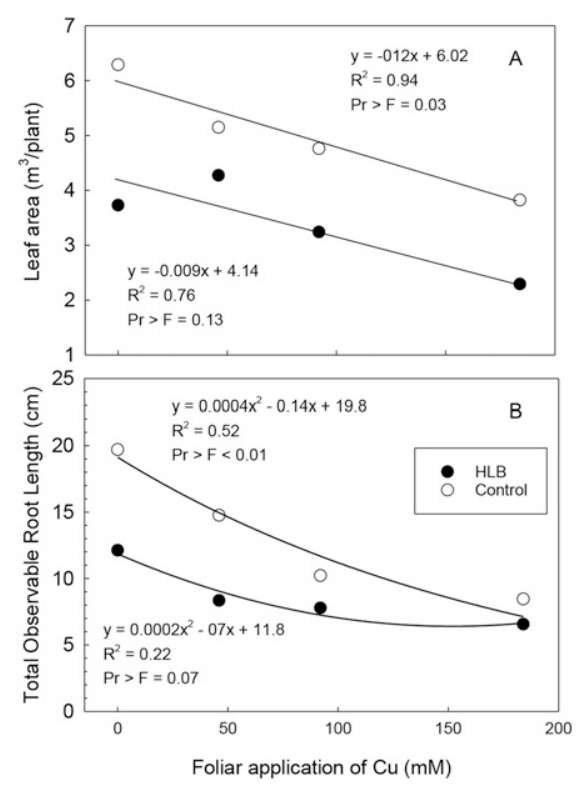

Fig. 4. Leaf area in Aug. 2017 (A) and total root length visible (B) in the rhizotron tubes and averaged across all sampling dates of Citrus sinensis cv. Valencia as affected by Huanglongbing (HLB) and foliar applications of copper $(\mathrm{Cu})(\mathrm{n}=3)$. Symbols for HLB treatments are in the legend in the lower graph. Data used in the regression analyses were averaged across all sampling dates after the first $\mathrm{Cu}$ treatment was applied for each replication (tree); however, only overall means are shown in the graph.

taken Feb. 2016, before the experiment was initiated, by determining the $\mathrm{Cu}$ treatment $x$ MAFT interaction (analysis not shown). This analysis tested the change in $\mathrm{Ct}$ values to determine whether $\mathrm{Cu}$ affected proliferation of the bacterial genome copy number. The $\mathrm{Cu}$ treatment $\times$ MAFT interaction was not significant $(P>\mathrm{F}=0.96)$, indicating that the change in genome copy number was unaffected by $\mathrm{Cu}$ treatment. The average $\mathrm{Ct}$ values for HLB-affected plants were 24.9 in Feb. 2016 and 29.4 in Oct. 2016.

CLasiaticus and Xcc are both Gramnegative bacteria, and it is reasonable to consider that $\mathrm{Cu}$ would inhibit both pathogens. However, Xcc is limited to the apoplast. It is deposited on the exterior of leaves during rain events and it uses its flagella to move through stomatal apertures and into substomatal chambers (Gottwald and Graham, 1992; Koizumi and Kuhara, 1982; Stall et al., 1982), where it attaches to cell walls to begin the pathogenesis process (Brunings and Gabriel, 2003). When $\mathrm{Cu}$ is applied to the foliage, it moves via diffusion into the leaf through the apoplast, where it comes into direct contact with the bacteria. CLasiaticus, on the other hand, resides in the symplast of phloem sieve tubes. The symplast limits $\mathrm{Cu}$ concentrations to within a narrow range by reducing uptake and/or pumping excess into the apoplast, where it diffuses to the leaf surface and is removed by precipitation (Marschner, 1995). Most of the $\mathrm{Cu}$ applied to foliage does not come into direct contact with CLasiaticus, and thus it is not surprising that the foliar applications of $\mathrm{Cu}$ in the current study did not affect the CLasiaticus genome copy numbers as measured by the $\mathrm{Ct}$ values of the leaves.

Vegetative growth. Although the HLBaffected and control trees began the study with similar leaf area, there was a significant $\mathrm{HLB} \times \mathrm{Cu} \times$ MAFT interaction (Table $1 ; P>$ $\mathrm{F}=0.03$ ), with HLB and greater $\mathrm{Cu}$ treatments suppressing growth of the canopy's leaf area (Fig. 3). Although the HLB $\times \mathrm{Cu}$ treatment interaction when averaged across all sampling dates was also significant $(P>\mathrm{F}$ $<0.01)$, the interaction was not strong at the end of the experiment (Fig. 4A). Total leaf area in Aug. 2017 declined across $\mathrm{Cu}$ treatments for both HLB-affected and control plants, with only a slight difference in slopes. Leaf area averaged 32\% less for HLBaffected leaves than controls across all $\mathrm{Cu}$ treatments. These data indicate that the impact of HLB and $\mathrm{Cu}$ treatments on leaf area were additive.

Total observable root length demonstrated significant HLB $\times$ MAFT $(P>\mathrm{F}=$ $0.02)$ and $\mathrm{Cu} \times$ MAFT $(P>\mathrm{F}=0.02)$ interactions (Table 1$)$. The greater variation in total observable root length across time (Fig. 3) is typical of root growth of plants, which for citrus varies in part based on stage of growth flushes (Bevington and Castle, 1985) and application of essential nutrients (Marschner, 1995). To simplify understanding the impact of HLB and $\mathrm{Cu}$ treatment on root growth, data were averaged across all dates for each tree and subjected to polynomial analysis, with quadratic regressions giving better fits (greater $R^{2}$ values) than linear regressions (Fig. 4B). Total root length of the HLB-affected roots was $40 \%$ less than the controls for the $0 \mathrm{x} \mathrm{Cu}$ treatment; however, increasing concentrations of applied $\mathrm{Cu}$ depressed total observable root length more so for the controls than the HLB-affected plants, such that they were similar at the greatest $\mathrm{Cu}$ treatment.

By the end of the experiment, total leaf, stem, root, and whole-plant dry weights were reduced by both HLB and $\mathrm{Cu}$ treatments. The $\mathrm{HLB} \times \mathrm{Cu}$ treatment interactions were not significantly different for total leaf $(P>\mathrm{F}=$ $0.88)$, root $(P>\mathrm{F}=0.55)$, and whole-plant $(P>\mathrm{F}=0.38)$ dry weights; however, the HLB and $\mathrm{Cu}$ treatment main effect means were all significant at $P>\mathrm{F}<0.01$ (Table 1). For stem dry weights, there was a significant HLB $\times$ $\mathrm{Cu}$ treatment interaction $(P>\mathrm{F}=0.04)$. All dry weights were suppressed by HLB and $\mathrm{Cu}$ treatments, including the $0.5 \mathrm{x} \mathrm{Cu}$ treatment (Fig. 5). The HLB and $\mathrm{Cu}$ treatment suppression of growth was additive for leaf, root, and total plant dry weight as a result of the lack of significant $\mathrm{HLB} \times \mathrm{Cu}$ treatment interactions and the similarity in slopes.

Soil $p H$. Soil $\mathrm{pH}$ did not differ between HLB $(\mathrm{pH}=6.71)$ and controls $(\mathrm{pH}=6.67)$ before the first $\mathrm{Cu}$ treatments were applied. The HLB $\times$ MAFT interaction was significant (Table $1 ; P>\mathrm{F}<0.01$ ) so that by Jan. 2017, soil $\mathrm{pH}$ of soil containing HLB-affected trees was 5.96, whereas the soil $\mathrm{pH}$ of the controls was 6.36 , which represents a 0.40 difference. $\mathrm{Cu}$ treatments did not impact soil $\mathrm{pH}$. Low soil $\mathrm{pH}$ increases $\mathrm{Cu}$ availability, which in turn promotes uptake by plant roots (Harter, 1983; Sims, 1986; Smith, 1994) — a fact on which $\mathrm{Cu}$ application recommendations of 


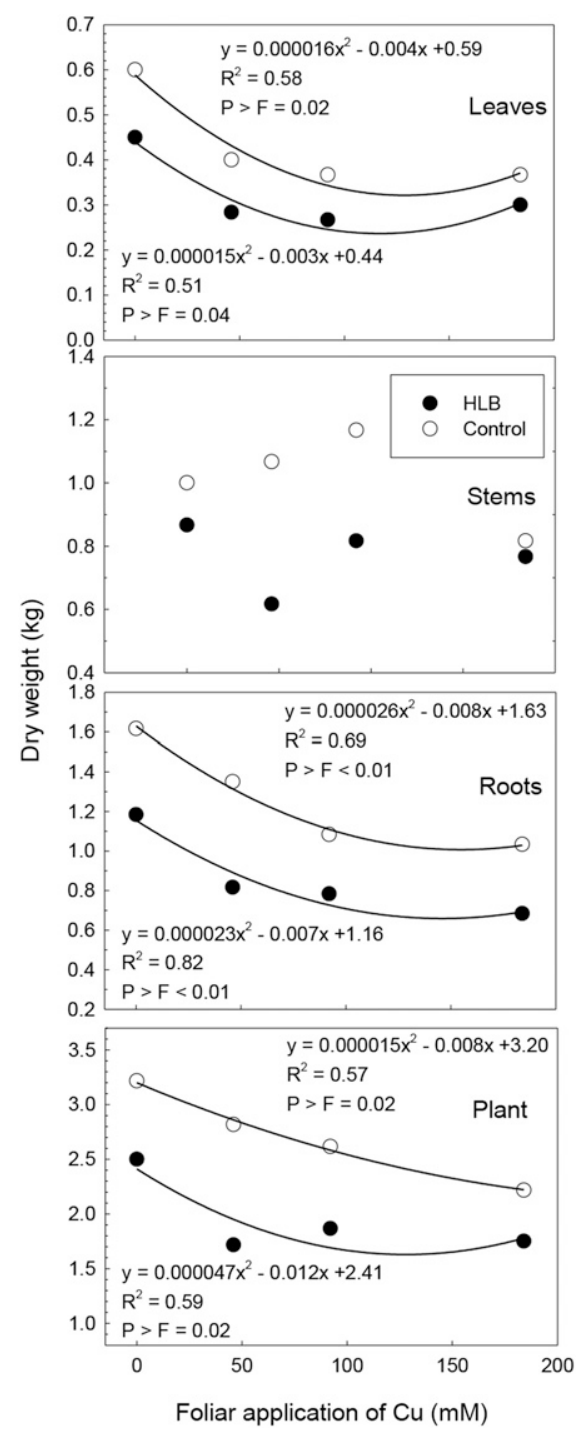

Fig. 5. Interaction of Huanglongbing (HLB) and foliar applications of copper $(\mathrm{Cu})$ on leaf, stem, root and whole-plant dry weights of Citrus sinensis $\mathrm{cv}$. Valencia at the end of the experiment $(\mathrm{n}=3)$. Symbols for HLB treatments are in the legend in the second graph. Data used in the regression analyses were averaged across all sampling dates after the first $\mathrm{Cu}$ treatment was applied for each replication (tree); however, only overall means are shown in the graph.

citrus in Florida are based (Obreza and Morgan, 2008). Thus, the greater acidification of soil by HLB-affected roots increased $\mathrm{Cu}$ availability, which promoted uptake and greater $\mathrm{Cu}$ concentrations in leaves and roots compared with the non-HLB controls.

Essential nutrients: Macronutrients $N, P$, and $K$, and $B$. The inconsistent timing in fertilization of essential nutrients other than $\mathrm{Cu}$ makes analyzing foliar and root concentrations as a repeated measure inappropriate. Therefore, the data were analyzed using the GLM procedure with the data blocked by time (MAFT) to remove variation caused by measurements for the different sampling dates. There was no effect of HLB or $\mathrm{Cu}$ on $\mathrm{N}, \mathrm{P}, \mathrm{K}$, and $\mathrm{B}$ on foliar (Table 2) or root

Table 2. Results of the Proc Mixed model $(P>$ F) on leaf concentrations of essential nutrients of Huanglongbing (HLB)-affected 'Valencia' trees treated with multiple foliar applications of copper $(\mathrm{Cu})$ and with dependent variables measured over time.

\begin{tabular}{|c|c|c|c|c|c|c|c|c|c|}
\hline \multirow{2}{*}{$\begin{array}{l}\text { Model variables } \\
\text { and interactions }\end{array}$} & \multicolumn{4}{|c|}{ Macronutrients and boron } & \multicolumn{5}{|c|}{ Divalent cations } \\
\hline & $\mathrm{N}$ & $\mathrm{K}$ & $\mathrm{P}$ & B & $\mathrm{Ca}$ & $\mathrm{Mg}$ & $\mathrm{Fe}$ & $\mathrm{Mn}$ & $\mathrm{Zn}$ \\
\hline & & & & $P>\mathrm{F}$ & & & & & \\
\hline \multicolumn{10}{|l|}{ Model } \\
\hline HLB & 0.75 & 0.41 & 0.59 & 0.30 & 0.02 & 0.04 & 0.18 & $<0.01$ & $<0.01$ \\
\hline $\mathrm{Cu}$ & 0.42 & 0.49 & 0.44 & 0.75 & 0.19 & 0.65 & 0.16 & 0.15 & 0.36 \\
\hline $\mathrm{HLB} \times \mathrm{Cu}$ & 0.39 & 0.66 & 0.57 & 0.37 & 0.87 & 0.93 & 0.15 & 0.35 & 0.25 \\
\hline MAFT & $<0.01$ & $<0.01$ & $<0.01$ & $<0.01$ & $<0.01$ & $<0.01$ & $<0.01$ & $<0.01$ & $<0.01$ \\
\hline Main effect means & \multicolumn{3}{|c|}{$(\%)$} & $(\mathrm{mg} / \mathrm{kg})$ & \multicolumn{2}{|c|}{$(\%)$} & \multicolumn{3}{|c|}{$(\mathrm{mg} / \mathrm{kg})$} \\
\hline HLB treatment & & & & & & & & & \\
\hline Control & 3.3 & 2.6 & 0.14 & 215 & $2.2 \mathrm{a}$ & $0.29 \mathrm{a}$ & 97 & $147 \mathrm{a}$ & $65 \mathrm{a}$ \\
\hline HLB & 3.4 & 2.6 & 0.14 & 204 & $2.0 \mathrm{~b}$ & $0.26 \mathrm{~b}$ & 83 & $99 \mathrm{~b}$ & $50 \mathrm{~b}$ \\
\hline \multicolumn{10}{|l|}{$\mathrm{Cu}$ treatment } \\
\hline $0 \times$ & 3.3 & 2.6 & 0.15 & 213 & 2.2 & 0.28 & 103 & 141 & 77 \\
\hline $0.5 \times$ & 3.3 & 2.7 & 0.14 & 202 & 2.2 & 0.27 & 98 & 103 & 78 \\
\hline $1 \times$ & 3.4 & 2.6 & 0.14 & 216 & 2.0 & 0.29 & 85 & 126 & 77 \\
\hline $2 x$ & 3.4 & 2.5 & 0.13 & 206 & 2.1 & 0.27 & 74 & 122 & 66 \\
\hline $\begin{array}{l}\text { Recommended } \\
\text { levels }\end{array}$ & $2.5-2.7$ & $0.7-1.1$ & $0.12-0.16$ & $36-100$ & $3.0-4.9$ & $0.3-0.49$ & $60-120$ & $25-100$ & $25-100$ \\
\hline
\end{tabular}

From Obreza and Morgan (2008).

Bold values are referenced in the text. Letters within columns indicate significant differences among main effect means when the $P>\mathrm{F} \leq 0.05$.

$\mathrm{N}=$ nitrogen $\mathrm{K}=$ potassium $; \mathrm{P}=$ phosphorus $; \mathrm{B}=$ boron $; \mathrm{Ca}=$ calcium $; \mathrm{Mg}=$ magnesium; $\mathrm{Fe}=$ iron; $\mathrm{Mn}=$ manganese; $\mathrm{Zn}=$ zinc; MAFT $=$ months after foliar treatment with $\mathrm{Cu}(\mathrm{n}=6)$.

(analyses not shown) concentrations. None of the foliar concentrations of these essential nutrients were deficient.

Divalent cations $\mathrm{Ca}, \mathrm{Mg}, \mathrm{Fe}, \mathrm{Mn}$, and $\mathrm{Zn}$. HLB has been shown to affect the acquisition and distribution of essential nutrients, with suppression in foliar concentrations of $\mathrm{Ca}$, $\mathrm{Mg}, \mathrm{Fe}, \mathrm{Mn}$, and $\mathrm{Zn}$ being the most often reported (Aubert, 1979; Handique et al., 2012; Koen and Langenegger, 1970; Masaoka et al., 2011; Nwugo et al., 2013a, 2013b; Pustika et al., 2008; Spann and Schumann, 2009; Tian et al., 2014). Foliar concentrations of most of these nutrients were suppressed by HLB $(P>$ $\mathrm{F}<0.05$ ) in the current study (Table 2), although the analysis for $\mathrm{Fe}$ was not strong $(P>\mathrm{F}=0.18)$. HLB did not affect concentrations of any divalent cations in the roots (analyses not shown), indicating that although acquisition by roots appeared not to be affected by HLB, their transport to the shoots was reduced.

Acquisition of essential nutrients by plants is a function of several factors including, in part, the 1) relative external concentrations of essential nutrients that have similar valences, 2) closeness of their ionic radii, and 3) soil chemistry, which affects hydration and ionic interactions with the surface of soil particles and other ions and polar molecules (Marschner, 1995). The average soil concentrations of $\mathrm{Ca}, \mathrm{Mg}, \mathrm{Fe}, \mathrm{Mn}$, and $\mathrm{Zn}$ across all sampling dates were 478 , $59,111,17$, and $7 \mathrm{mg} / \mathrm{kg}$ dry weight, respectively, whereas $\mathrm{Cu}$ was as much as 60 $\mathrm{mg} / \mathrm{kg}$ dry weight in the soil for the greatest $\mathrm{Cu}$ treatment. The nonhydrated forms of the divalent cations $\mathrm{Mg}, \mathrm{Fe}, \mathrm{Mn}, \mathrm{Zn}$, and $\mathrm{Cu}$ have ionic radii that are within $10 \%$ of each other (Shannon, 1976; Wells, 1984), and therefore it would be expected that they would tend to compete for uptake by plant roots (Marschner, 1995). Competition for uptake among divalent cations has been shown in citrus (Martínez-Cuenca et al., 2013; Reuther et al., 1952; Smith and Specht, 1953; Srivastava and Singh, 2005); however, a survey of the literature for citrus revealed that the only divalent cation with an uptake affected by high $\mathrm{Cu}$ in soil is Fe (Smith and Specht, 1953). In the current study, the high soil $\mathrm{Cu}$ may have suppressed uptake of Fe for HLB and nonHLB control trees $(P>\mathrm{F}=0.16)$, where foliar Fe concentrations decreased numerically from 103 to $74 \mathrm{mg} \mathrm{Fe} / \mathrm{kg}$ dry weight with increasing $\mathrm{Cu}$ applied. A more intensive study on the interaction in uptake by the various divalent cations for HLB-affected roots should be conducted to determine the conditions that promote deficiencies in commercial groves.

\section{Conclusions}

HLB-affected roots acidified the soil more than non-HLB controls, which increased $\mathrm{Cu}$ availability and promoted uptake and greater $\mathrm{Cu}$ concentrations in roots and leaves. Excessive levels of $\mathrm{Cu}$ were reached in HLB-affected plants at lower foliar application treatments of $\mathrm{Cu}$, which contributed to suppressed growth. As has been shown in other studies, HLB suppressed foliar concentrations of the divalent cations $\mathrm{Ca}, \mathrm{Mg}, \mathrm{Mn}, \mathrm{Zn}$, and possibly $\mathrm{Fe}$. $\mathrm{Cu}$ did not affect uptake and foliar or root concentrations of most other essential nutrients except possibly Fe.

\section{Literature Cited}

Anderson, D. and L. Henderson. 1988. Comparing sealed chamber digestion with other digestion methods used for plant-tissue analysis. Agron. J. 80:549-552.

Aubert, B. 1979. Progrès accompli dans la lutte contre le greening des citrus à la Réunion. Revue Agricole Sucrière 58:53-56.

Bakshi, S., Z.L. He, and W.G. Harris. 2013 Particulate copper in soils and surface runoff 
from contaminated sandy soils under citrus production. Environ. Sci. Pollut. Res. Intl. 20: 8801-8812.

Behlau, F., J. Belasque, Jr., J.H. Graham, and R.P. Leite, Jr. 2010. Effect of frequency of copper applications on control of citrus canker and the yield of young bearing sweet orange trees. Crop Prot. 29:300-305.

Bevington, K.B. and W.S. Castle. 1985. Annual root growth pattern of young citrus trees in relation to shoot growth, soil temperature, and soil water content. J. Amer. Soc. Hort. Sci. 110:840-845.

Bouffard, K. 2006. Canker eradication era ends. The Ledger, Oct. 6.

Bové, J.M. 2006. Huanglongbing: A destructive, newly-emerging, century-old disease of citrus. J. Plant Pathol. 88:7-37.

Brunings, A.M. and D.W. Gabriel. 2003. Xanthomonas citri: Breaking the surface. Mol. Plant Pathol. 4:141-157.

da Graça, J.V., G.W. Douhan, S.E. Halbert, M.L. Keremane, R.F. Lee, G. Vidalakis, and H. Zhao. 2016. Huanglongbing: An overview of a complex pathosystems ravaging the world's citrus. 2016. J. Integr. Plant Biol. 58:373-387.

Ebel, R.C. 2017. Huanglongbing: Mechanism of citrus decline and horticulture management in Florida. Integrated Plant Health Services, Fort Myers, FL. 17 Jan. 2019. <www.IPHSLLC. com>.

Ebel, R.C. and N. Kumar. 2012. Interference of oxidative metabolism in citrus by Xanthomonas citri pv citri, p. 169-188. In: V.I. Lushchak (ed.). Oxidative stress: Environmental induction and dietary antioxidants. InTech, Rijeka, Croatia. This open-access publication can be found at $<$ https://www.intechopen.com/books/ oxidative-stress-environmental-induction-anddietary-antioxidants/interference-of-oxidativemetabolism-in-citrus-by-xanthomas-citri-pv-citrithe-causal-agent-of-citr>.

Fan, J., Z. He, L.Q. Ma, and P.J. Stoffella. 2011. Accumulation and availability of copper in citrus grove soils as affected by fungicide application. J. Soils Sediments 11:639-648.

Gottwald, T.R. 2010. Current epidemiological understanding of citrus Huanglongbing. Annu. Rev. Phytopathol. 48:119-139.

Gottwald, T.R. and J.H. Graham. 1992. A device for precise and nondisruptive stomatal inoculation of leaf tissue with bacterial pathogens. Phytopathology 82:9930-9935.

Gottwald, T.R. and J.H. Graham. 2000. Canker, p. 5-7. In: L.W. Timmer, S.M. Garnsey, and J.H. Graham (eds.). Compendium of citrus diseases, 2nd ed. APS Press, St. Paul, MN.

Hamido, S.A., K.T. Morgan, and D.M. Kadyampakeni. 2017. The effect of Huanglongbing on young citrus tree water use. HortTechnology 27:659-665.

Handique, U., R.C. Ebel, and K.T. Morgan. 2012. Influence of soil-applied fertilizer on greening development in new growth flushes of sweet orange. Proc. Annu. Meet. Fla. State Hort. Soc. 125:36-40.

Hanlon, E.A., J.S. Gonzalez, and J.M. Bartos. 1997. Institute of Food and Agricultural Sciences (IFAS) Extension Soil Testing Laboratory (ESTL) and Analytical Research Laboratory (ARL) chemical procedures and training manual. Circ. vol. 812. Univ. of Florida, Gainesville.

Harter, R.D. 1983. Effect of soil on adsorption of lead, copper, zinc, and nickel. Soil Sci. Soc. Amer. J. 47:47-51.

Jones, J.B.J. and V.W. Case. 1990. Sample, handling, and analyzing plant tissue samples, $\mathrm{p}$. 389-427. In: R.L. Westerman (ed.). Soil testing and plant analysis. Soil Science Society of America, Madison, WI.

Koen, T.J. and W. Langenegger. 1970. Effect of greening virus on the macroelement content of citrus leaves. Farming South Afr. 45:1-65.

Koizumi, M. and S. Kuhara. 1982. Evaluation of citrus plants for resistance to bacterial canker disease in relation to lesion extension. Bull. Tree Fruit Res. D 4:73-92.

Li, W., J.S. Hartung, and L. Levy. 2006. Quantitative real-time PCR for detection and identification of Candidatus Liberibacter species associated with citrus Huanglongbing. J. Microbiol. Methods 66:104-115.

Marschner, H. 1995. Mineral nutrition of higher plants. Academic Press, San Diego, CA.

Martínez-Cuenca, M.-R., A. Quiñones, D.J. Iglesias, M.Á. Forner-Giner, E. Primo-Millo, and F. Legaz. 2013. Effects of high levels of zinc and manganese ions on strategy I responses to iron deficiency in citrus. Plant Soil 373:943-953.

Masaoka, Y., A. Pustika, S. Subandiyah, A. Okada, E. Hanundin, B. Purwanto, M. Okuda, Y. Okada, A. Saito, P. Holford, A. Beattie, and T. Iwanami. 2011. Lower concentrations of microelements in leaves of citrus infected with 'Candidatus Liberibacter asiaticus'. Jpn. Agr. Res. Qrtly. 45:269-275.

Mehlich, A. 1984. Mehlich 3 Soil Test Extractant: A modification of Mehlich 2 Extractant. Commun. Soil Sci. Plant Anal. 15(12):1409-1416.

Munter, R., T. Halverson, and R. Anderson. 1984. Quality assurance for plant tissue analysis by ICP-AES. Commun. Soil Sci. Plant Anal. 15:1285-1322.

Nwugo, C.C., Y. Duan, and H. Lin. 2013a. Study on citrus response to Huanglongbing highlights a down-regulation of defense-related proteins in lemon plants upon ' $\mathrm{Ca}$. Liberibacter asiaticus' infection. Publ. Lib. Sci. 8:113.

Nwugo, C.C., H. Lin, Y. Duan, and E.L. Civerolo. 2013b. The effect of 'Candidatus Liberibacter asiaticus' infection on the proteomic profiles and nutritional status of pre-symptomatic and symptomatic grapefruit
(Citrus paradisi) plants. BioMed. Central. Plant Biol. 13:1-24.

Obreza, T.A. and K.T. Morgan. 2008. Nutrition of Florida citrus trees. Cooperative Extension Service, University of Florida, Institute of Food and Agricultural Sciences, Gainesville, FL.

Obreza, T.A., R.E. Rouse, and J.B. Sherrod. 1999. Economics of controlled-release fertilizer use on young citrus trees. J. Prod. Agr. 12:69-73.

Plank, C.O. 1992. Plant analysis reference procedures for the southern region of the United States. Southern Coop. Ser. Bull. 368. Crop Soil Sci. Dep., Univ. of Georgia, Athens. 17 Jan. 2019. <http://www.clemson.edu/sera6/Plant $\%$ 20 Analysis\%20Reference $\% 20$ Procedures. rdo.pdf $>$.

Pustika, A.B., S. Subandiyah, P. Holford, G.A.C. Beattie, T. Iwanami, and Y. Masoka. 2008. Interactions between plant nutrition and symptom expression in mandarin trees infected with the disease Huanglongbing. Australas. Plant Dis. Notes 3:112-115.

Reuther, W., P.F. Smith, and A.W. Specht. 1952. Accumulation of the major bases and heavy metals in Florida citrus soils in relation to phosphate fertilization. Soil Sci. 73:375-382.

Shannon, R.D. 1976. Revised effective ionic radii and systematic studies of interatomic distances in halides and chalcogenides. Acta Crystallogr. A 32:751-767.

Sims, T.J. 1986. Soil pH effects on the distribution and plant availability of manganese, copper, and zinc. Soil Sci. Soc. Amer. J. 50:367-373.

Smith, S.R. 1994. Effect of soil pH on availability to crops of metals in sewage sludge-treated soils. I: Nickel, copper and zinc uptake and toxicity to ryegrass. Environ. Pollut. 85:321327.

Smith, P.F. and A.W. Specht. 1953. Heavy-metal nutrition and iron chlorosis of citrus seedlings. Plant Physiol. 28:371-382.

Spann, T.M. and A.W. Schumann. 2009. The role of plant nutrients in disease development with emphasis on citrus and Huanglongbing. Proc. Annu. Meet. Fla. State Hort. Soc. 122:169 171.

Srivastava, A.K. and S. Singh. 2005. Zinc nutrition, a global concern for sustainable citrus production. J. Sustain. Agr. 25:5-42.

Stall, R.E., G.M. Marco, and B.I. Canderos de Echenique. 1982. Importance of mesophyll in mature-leaf resistance to cancrosis of citrus. Phytopathology 72:1097-1100.

Tian, S., L. Lu, J.M. Labavitch, S.M. Webb, X. Yang, P.H. Brown, and Z. He. 2014. Spatial imaging of $\mathrm{Zn}$ and other elements in Huanglongbingaffected grapefruit by synchrotron-based micro $\mathrm{X}$-ray fluorescence investigation. J. Expt. Bot. 65:953-964.

Wells, A.F. 1984. Structural inorganic chemistry. 5th ed. Clarendon Press, Oxford, UK. 